\title{
Phytogeographical and sociolinguistical patterns of the diversity, distribution, and uses of wild mushrooms in Côte d'Ivoire, West Africa
}

Bakary Soro ${ }^{1,2}$, N'golo Abdoulaye Koné ${ }^{12^{*}}$ (D), Linda Patricia Louyounan Vanié-Léabo ${ }^{3}$, Souleymane Konaté1,3, Adama Bakayoko ${ }^{1}$ and Daouda Koné3

\begin{abstract}
Background: Many fungal species in tropical Africa are useful, with high added value, and play essential roles in the structure and dynamic of ecosystems. However, the diversity, distribution, and uses by local populations of these non-timber forest products (NTFPs) and their respective habitats are still very poorly understood in subSaharan Africa in general and more specifically in Côte d'Ivoire. This study aims at (i) inventorying the wild useful mushrooms of Côte d'Ivoire within its major protected areas and their respective surrounding sociolinguistical groups, according to climatic and phytogeographical gradients, and (ii) recording ethnomycological knowledge and considerations of these local people.

Methods: Field and ethnomycological surveys were conducted in the main and highest protected areas of Côte d'Ivoire (Comoé, Marahoué, and Taï national parks) and a set of their respective surrounding villages, along climatic and phytogeographical gradients. Standardized methods (permanent plots and opportunistic searches) were used for field surveys. In addition, a total 748 respondents belonging to 13 ethnic groups were interviewed at a rate of 300 interviewees during the preliminary investigations and 448 persons during the proper ethnomycological surveys.

Results: Sixty-eight useful wild fungal species, belonging to 17 families and 23 genera, were listed and collected. Four categories of usage were reported by the rural people (food, medicinal, belief and recreational), with a dominance of food and medicinal uses. Fifty-six species were reported to be used as food and 16 species as medicinal fungi. These uses varied not only from one sociolinguistical group to another but also from a visited village to another. The high number (41) of the reported useful species was found in the Sudano-Guinean savanna zone while 28 species were collected in the forest zone and 22 species in the forest-savanna mosaic zone. These mushrooms were either saprotrophic or symbiotic (ectomycorrhizal or termitophilic). Auricularia sp3, Psathyrella tuberculata, and Termitomyces spp. were found as the most commonly used mushrooms.

(Continued on next page)
\end{abstract}

\footnotetext{
* Correspondence: ngolo197804@yahoo.fr

'Université Nangui Abrogoua, UFR des Sciences de la Nature (UFR-SN), Unité de Recherche en Ecologie et Biodiversité (UREB), 28 BP 847 28, Abidjan, Côte d'Ivoire

${ }^{2}$ Centre de Recherche en écologie (CRE), Station de Recherche en Ecologie

du Parc National de la Comoé, Bouna, Côte d'Ivoire

Full list of author information is available at the end of the article
}

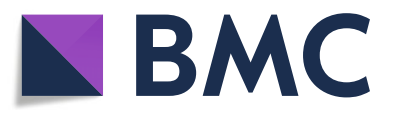

(c) The Author(s). 2019 Open Access This article is distributed under the terms of the Creative Commons Attribution 4.0 International License (http://creativecommons.org/licenses/by/4.0/), which permits unrestricted use, distribution, and reproduction in any medium, provided you give appropriate credit to the original author(s) and the source, provide a link to the Creative Commons license, and indicate if changes were made. The Creative Commons Public Domain Dedication waiver (http://creativecommons.org/publicdomain/zero/1.0/) applies to the data made available in this article, unless otherwise stated. 
(Continued from previous page)

Conclusions: These national scale field and ethnomycological surveys give one of the more complete but nonexhaustive list of useful mushrooms of Côte d'Ivoire. Mushrooms are relatively well known and used by the Ivorian people within the main phytogeographical zone of the country. These people also have an interest in all the functional groups with an important phytogeographical zone-fungal-specific used species. However, protected areas of the visited zones seem to represent the last sanctuaries of these organisms due to high rate of loss of natural habitats.

Keywords: Wild useful mushrooms, Diversity, Distribution, Sociolinguistic Indigenous knowledge, Ethnomycology, Côte d'Ivoire

\section{Background}

The diet of West African people partly depends on edible products from animals (caterpillar, snail), plants (leaves, fruits), or mushrooms [1]. There is a renewed of interest for such products mainly due to the high cost of living, imported (wheat flour, rice) and local agriculture's products (beans, corn, millet). Wild edible mushrooms are harvested in huge quantities, widely consumed and sold during their respective fructification periods, in Eastern [2, 3], Central $[4,5]$, and Western $[6,7]$ Africa. These organisms represent a real additional source of income for rural women and young [7]. In addition to the fact of being appreciated for their nutritional values $[8,9]$, these non-timber forest products (NTFPs) are at the origin of several dietary, ethnic, cultural, religious, or medicinal considerations depending on the ethnic groups $[10,11]$.

The global diversity of fungi is estimated to be 1.5 million species worldwide $[12,13]$. However, only $7 \%$ of this diversity is known [14]. The percentage of this known diversity hardly exceeds 3\% in West Africa [15]. However, within Africa, edible mushrooms are relatively well known in Central, Southern, and Eastern Africa [3, 16-18]. In sub-Saharan Africa, roughly 300 edible mushrooms have been identified and described even tough an annual consumption of more than $30 \mathrm{~kg}$ per rural inhabitant, particularly in Central and Southern Africa [6, 19, 20]. Furthermore, on a total of 151 references on African edible mushrooms, only three are related to West Africa [21-23].

The practical and applied interests of mushrooms are huge [14], in human nutrition (wild and cultivated edible species), agriculture, and forestry (bioindicator species, regulation of ecosystem functioning and dynamic, or uses in forest regeneration), industry (species used in biotechnology), pharmacy and medicine (species used in medicine), etc. However, some fungal species (i.e., Termitomyces spp.) are declining in abundance and diversity from year to year, due (1) to their bad and uncontrolled harvest for consumption (trade) and secondly (2) to the increasing reduction of their living habitats mainly attributable to forest fragmentation, shifting slash and burn cultivation, and extensive farming [7]. Furthermore, selective (focused on specific tree species) and/or massive cutting down of woodlands is not only inevitably accompanied by qualitative erosion of wild mushroom diversity but also by the drastic reduction in the quantitative availability of fungal food resources (cf. edible ectomycorrhizal mushrooms). For example, 28 endangered edible species were recorded in Benin, due to the permanent reduction of their habitats [24]. Côte d'Ivoire for its part is characterized by an annual loss of natural ecosystems of around 300,000 ha/year [25]. This massive destruction of habitats inevitably leads to serious losses of useful plants, mushrooms, and animal resources. This is a real threat to the survival of local people who exploit such resources on a daily basis. However, various phytogeographical zones are encountered in Côte d'Ivoire; including the Guinean, SudanoGuinean, and Sudanese zones. This phytogeographical heterogeneity includes diverse vegetation types which in turn strongly influence mycoflora $[6,26]$. There is no doubt that such mycofloristic variability and its potential consequent indigenous ethnomycological knowledge exist in Côte d'Ivoire.

This study aimed at (i) inventorying the wild useful mushrooms of Côte d'Ivoire within its major protected areas and their respective surrounding sociolinguistical groups according to a climatic and phytogeographical gradients and (ii) recording ethnomycological knowledge and considerations of these local people. In sum, the hypothesis that the diversity of mushrooms in Côte d'Ivoire, the ethnomycological knowledge of the Ivorian people, and their uses of these mushrooms are phytogeographical and sociolinguistical group dependent.

\section{Methods}

Study areas: the Ivorian national parks and some of their respective surrounding villages

This work was done in three national parks (Taï, Marahoué, and Comoé) and their surrounding areas, according to a phytogeographical and climatic gradient in 
Côte d'Ivoire (West Africa). The Fig. 1 presents the location of these study areas while the Table 1 shows the characteristics of each visited park with its respective vegetation types, visited villages, and ethnic groups interviewed during ethnomycological surveys.

\section{Choosing study sites and identifying mycophagous ethnic groups}

Preliminary ethnomycological investigations were carried out on 300 people, at the rate of 100 persons per phytogeographical zone, for the determination of the indigenous knowledge of respective communities. The questionnaires and casual conservations were structured around five main points: (i) the availability of wild mushrooms in the visited localities; (ii) indigenous knowledge and especially the uses of wild mushrooms by local populations; (iii) diversity and abundance of wild useful mushrooms; (iv) the market value of these wild useful mushrooms and the identification of actors of a potential seasonal trade of these fruit bodies; (v) fructification periods and habitats of these wild edible and medicinal mushrooms. This work has been done through household surveys and semi-structured interviews. These preliminary surveys were followed by a first field sampling surveys within the visited areas.

After the preliminary investigations and the first field sampling surveys, a common photo album was prepared with photos of all identified wild mushroom species and their respective habitat. This photo album was used for the proper ethnomycological surveys on 448 people [27], within the identified mycophagous ethnic groups of each phytogeographical zone. These surveys were conducted in the households, late in the afternoon or in the evening at farmers' home. Moreover, the rural markets, roads, and tracks leading to farms and localities bordering each national park were visited. These surveys were carried out by local assistants previously trained under our supervision during the preliminary investigations. These local assistants were selected in the villages on the basis of their botanical, mycological (vernacular names of trees and mushrooms ), and especially local language knowledge.

These proper ethnomycological surveys were mainly based on semi-structured interviews and casual conversations with rural people in the visited villages. The semi-structured interviews were based on previously defined questions while casual conversations were occasional. The questionnaires and casual conversations were structured around (i) the availability and diversity of the wild useful mushrooms, (ii) the specific uses of each reported species, (iii) the fructification periods and habitats of each reported species, and (iv) the fungal harvesting methods.

The choice of the villages to be visited was based on the cultural considerations of the local people; not on their arrangement in the vicinity of the visited protected areas.

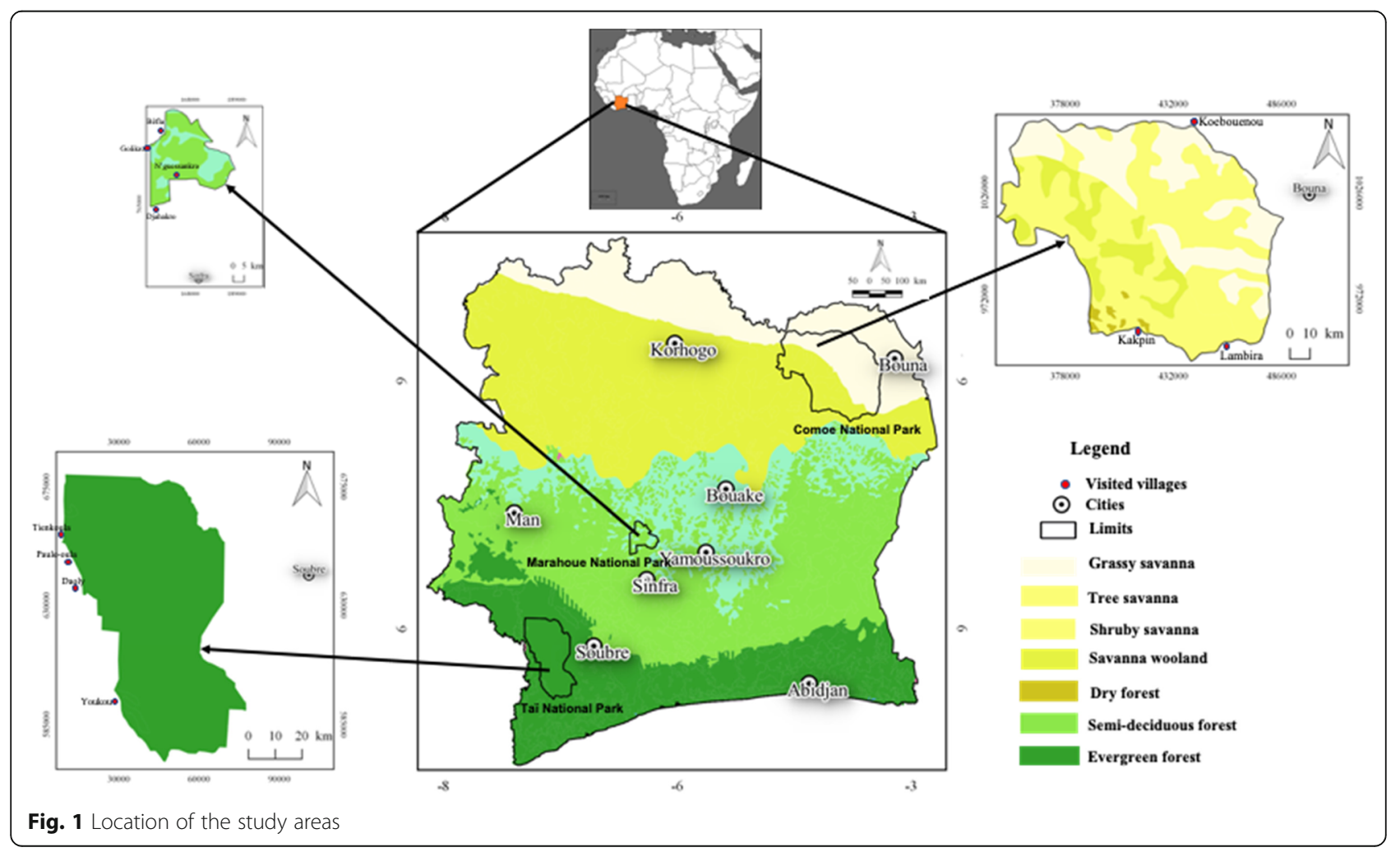


Table 1 Characteristics of the study areas

\begin{tabular}{|c|c|c|c|}
\hline Study zones & Characteristics & Visited villages & $\begin{array}{l}\text { Interviewed } \\
\text { sociolinguistical } \\
\text { groups }\end{array}$ \\
\hline $\begin{array}{l}\text { Evergreen Forest zone (EF)/Taï } \\
\text { National Park (TNP) }\end{array}$ & $\begin{array}{l}\text { Status: UNESCO World Heritage Site and Biosphere Reserve } \\
\text { Location: Southwestern Côte d'Ivoire }\left(5^{\circ} 08^{\prime}-6^{\circ} 24^{\prime} \mathrm{N} \text { and }\right. \\
\left.6^{\circ} 47^{\prime}-7^{\circ} 25^{\prime} \mathrm{W}\right) \\
\text { Size: } 4540 \mathrm{~km}{ }^{2} \\
\text { Vegetation: upper Guinean evergreen forest. } \\
\text { Climate: annual rainfall ranges from a mean of } 1700 \mathrm{~mm} \text { in } \\
\text { the north to } 2200 \mathrm{~mm} \text { in the southwest, falling from March } \\
\text { /April to July, with a shorter wet season from September to } \\
\text { October. } \\
\text { Particularity: the largest island of forest remaining in West } \\
\text { Africa, remaining relatively intact and well conserved. } \\
\text { Main anthropogenic impacts: threatened mammal species } \\
\text { such as the pygmy hippopotamus and } 11 \text { species of } \\
\text { monkeys are of great scientific interest. New main region } \\
\text { of cacao production of the country }\end{array}$ & $\begin{array}{l}\text { Paulé-oula, } \\
\text { Youkou, Tienkoula, } \\
\text { Daobly }\end{array}$ & $\begin{array}{l}\text { Oubi, Baoulé, Gouro, } \\
\text { Sénoufo, Kroumen, } \\
\text { Guéré }\end{array}$ \\
\hline $\begin{array}{l}\text { Guinean Savanna Zone } \\
\text { (GS)/Marahoué National } \\
\text { Park (MNP) }\end{array}$ & $\begin{array}{l}\text { Status: Endangered National Park } \\
\text { Location: West-center ( } 7^{\circ} 05^{\prime} 49^{\prime} \mathrm{N}-6^{\circ} 01^{\prime} 32^{\prime} \mathrm{W} \text { ) } \\
\text { Size: } 1010 \mathrm{~km} \mathrm{~km}^{2} \\
\text { Vegetation: forest-savanna mosaic (Guinean savanna) } \\
\text { Climate: mean annual precipitation varies between } 1100 \\
\text { and } 1800 \mathrm{~mm} \text {. Two dry periods can be distinguished, } \\
\text { stretching from November to February and from July to } \\
\text { August. } \\
\text { Particularity: covered with forest ( } 2 / 3 \text { ) and savanna. Four } \\
\text { main habitats types occur: open canopy forest, gallery } \\
\text { forests, forest-savanna edge, and savannas (savanna } \\
\text { woodland, tree savannas, and shrubby savannas). } \\
\text { Main anthropogenic impacts: illegal farming (illegal farms } \\
\text { cover huge areas in the former forest zone), poaching, and } \\
\text { fire. It has lost } 93 \% \text { of its forest cover in the last } 6 \text { years. }\end{array}$ & $\begin{array}{l}\text { Bêfla, Golikro, Djahakro, } \\
\text { N'guessankro }\end{array}$ & Gouro, Baoulé, Whan \\
\hline $\begin{array}{l}\text { Sudano-Guinean savanna zone } \\
\text { (SGS)/Comoé National } \\
\text { Park (CNP) }\end{array}$ & $\begin{array}{l}\text { Status: UNESCO World Heritage site and Biosphere Reserve } \\
\text { Location: North-eastern }\left(8^{\circ} 30^{\prime}-9^{\circ} 40^{\prime} \mathrm{N} \text { and } 3^{\circ} 10^{\prime}-4^{\circ} 20^{\prime} \mathrm{W} \text { ). }\right. \\
\text { Size: } 11,500 \mathrm{~km} \mathrm{~m}^{2} \\
\text { Climate: mean annual precipitation is around } 1150 \mathrm{~mm} \\
\text { with a mean annual temperature of } 27^{\circ} \mathrm{C} \text {. } \\
\text { Vegetation: semi-natural mosaic of forest-savanna (Sudano- } \\
\text { Guinean savanna). } \\
\text { Particularity: many habitats ranging from forests to } \\
\text { savannas, including all types } \\
\text { of savanna ( } 84 \% \text { ), bowal ( } 4.9 \%) \text {, gallery forest ( } 2.3 \% \text { ), and } \\
\text { dry and humid forest islands } \\
\text { Main anthropogenic impacts: uncontrolled annual fire }\end{array}$ & $\begin{array}{l}\text { Kakpin, Lambira, } \\
\text { Koebounou }\end{array}$ & $\begin{array}{l}\text { Koulango, Lobi, } \\
\text { Malinké, Lorhon }\end{array}$ \\
\hline
\end{tabular}

\section{Sampling design and visited habitat types}

Rapid assessment protocol via opportunistic searches was used for fungi sampling. Fruit bodies of wild mushrooms were collected in the national parks and their respective natural and anthropized surrounding habitats from 2014 to 2017. These opportunistic searches were completed with specific sampling methods respectively implemented within each phytogeographical zone:

-In the CNP, a total of 12 permanent plots of $30 \mathrm{~m} \times 30 \mathrm{~m}$ were established within 4 habitat types at a rate of 3 plots per habitat type. A gallery forest and tree habitats dominated by plants of Caesalpiniaceae and Phyllantaceae families were visited. Nine permanent plots were established in Isoberlinia doka Craib and Stapf, Uapaca togoensis Baill., and mixed woodlands (Isoberlinia doka Craib and Stapf + Uapaca togoensis Baill.) at a rate of tree plots per habitat type. Tree additional plots were established in a gallery forest;

-In the MNP, only opportunistic searches were undertaken within forests (forest islands, gallery forest) and savannah woodlands;

-In the TNP, nine plots of $30 \mathrm{~m} \times 30 \mathrm{~m}$ were established in strictly protected and rural evergreen forest habitats. Some opportunistic searches and collections were also done within some anthropized habitats such as cocoa, coffee, food crop plantations, and old fallows.

Photographs of the specimens were made in situ and macroscopic features' descriptions of the collected fruit bodies made on fresh samples using the standardized description form by [4] in order to record evanescent or changing features when drying. The specimens were then dried at a temperature of $40^{\circ} \mathrm{C}$ for 24 to $48 \mathrm{~h}$ and 
then packaged in 'Minigrip' plastic bags for future microscopic and anatomic studies.

\section{Indigenous knowledge and identification of useful wild mushrooms}

Ethnomycological knowledge within sociolinguistical groups was assessed by calculating the use frequencies of each reported fungal species within each use category. These values allowed determining scores for the calculation of some ethnomycological indices based on the 448 informants of the proper ethnomycological surveys:

-The reported use value (RUV) at the sociolinguistical group level;

-The ethnomycological use value of a species for a category of use (EUVk);

- The Cultural Significance Index (CSI) helped assessing and comparing the indigenous knowledge of useful fungal species within and between the visited sociolinguistical groups for the identification of the most used species per village and sociolinguistical group [28-30].

The first identifications and indigenous knowledge on the edibility and uses of the collected samples were made by the trained local assistants directly in the field. These fresh pre-identified specimens were then showed to the local populations for further indigenous knowledge (vernacular names, uses, and habitats). Furthermore, the photo album designed at the end of preliminary ethnomycological investigations and the first field works was also used. Every new indigenous knowledge or information (uses, vernacular name and its significance, and habitats) was judged as reliable after obtaining it from at least $75 \%$ of the informants within a specific sociolinguistical group and visited village.

\section{Identification of specimens}

The macroscopic and microscopic descriptions were made from exsiccata (dried fruit bodies) using conventional taxonomy techniques in mycology with a standardized description grid. These identifications were made on the basis of macro and microscopic observations, by consulting mushroom herbaria, field mushroom guides, and other standard-related available literature for Termitomyces species [3, 7, 31-33] and others species $[4,19,34,35]$.

\section{Results}

A total of 448 informants were interviewed during the proper ethnomycological survey, namely, 145 informants (32.37\%) in the Evergreen Forest zone, 131 informants (29.24\%) in the Guinean savanna zone, and 172 informants (38.39\%) in the Sudano-Guinean savanna zone. The informants were mainly women, not only at the total interviewees level $(63,62 \%)$ but also at the phytogeographical zone level (i.e., $20.98 \%$ in the EF, $15.85 \%$ in GS, and
$26.79 \%$ in SGS). Furthermore, informants of each ethnic group represent at least $12 \%$ of the total interviewees. The age of the informant range from 12 to 70 years.

\section{Diversity, abundance, and distribution of wild edible and medicinal mushrooms}

Sixty-eight wild edible and medicinal mushrooms species belonging to 23 genera and 17 families were recorded and identified (Table 2). These species belong to the functional groups of saprotrophic $(38.70 \%)$ and symbiotic $(60.30 \%)$ fungi. The symbiotic group was constituted of termitophilic (22.05\%) and ectomycorrhizal (38.23\%) fungal species. The diversity of these useful fungal species was found different from a phytogeographical zone to another.

Forty-one species were recorded in the Sudano-Guinean savanna zone while 28 species were identified in the Evergreen Forest zone and 22 species the Guinean savanna zone. The Sudano-Guinean savanna zone was dominated by the ectomychorizzal (Russulaceae and Amanitaceae) and termitophilic (Lyophyllaceae: Termitomyces spp.) species; while the extend forest-savanna boundaries (Guinean savanna) and the forest zone were dominated by the termitophilic and saprotrophic fungal species (Fig. 2). Most of the saprotrophic fungi were common to the visited phytogeographical zones as well as a termitophilic symbiotic species (Termitomyces medius) (Table 2).

The Cultural Significance Index values (CSI) showed a significant difference of the reported wild useful mushrooms' diversity between the interviewed sociolinguistical groups on the one hand and the visited villages on the other hand. Within the Evergreen Forest zone, in the localities of Paulé-oula and Daobly, the most used species belong is Auricularia sp3 by the Oubi and Gueré while Psathyrella tuberculatta and Volvariella volvacea species were identified as the most consumed species by the Baoulé. In the Guinean savanna zone, Psathyrella tuberculata was the most used mushroom by the Baoule and Gouro in the localities of Djahakro and Golikro. This species was also identified as the most used fungal species by the Koulango, Malinké, and Lobi in the localities of Kapkin and Lambira within the Sudano-Guinean savanna zone.

\section{Reported uses of wild mushrooms in Côte d'Ivoire}

Four categories: food, medicinal, belief (positioning) and myth (religious), and recreational (decoration and game) of usage were reported by the rural people with a dominance of food and medicinal uses. Whatever the phytogeographical zone, mushrooms were more used in diet than in local medicine. Fifty-six species were identified as food, and 16 species were used in local medicine (Table 2). Lycoperdon sp1 and Lycoperdon sp2 are used as games by kids while Ganoderma sp. is used for decoration, and Octaviana 
Table 2 Diversity and uses of useful wild mushrooms of Côte d'Ivoire

\begin{tabular}{|c|c|c|c|c|c|c|}
\hline Species & Families & $\begin{array}{l}\text { Voucher } \\
\text { number }\end{array}$ & Distribution & $\begin{array}{l}\text { Reported } \\
\text { uses }\end{array}$ & RUV & $\mathrm{Cll}$ \\
\hline Agaricus sp1 & Agaricaceae & SB190 & $\mathrm{EF}$ & Food & 0.41 & 0.29 \\
\hline Agaricus sp2 & & SB206 & EF & Food & 0.36 & 0.22 \\
\hline $\begin{array}{l}\text { Amanita congolensis (Beeli) Tulloss, } \\
\text { B. E. Wolfe, K. W. Hughes, Kudzma and Arora }\end{array}$ & Amanitaceae & LLPV110 & SGS & Food & 0.57 & 0.77 \\
\hline $\begin{array}{l}\text { Amanita masasiensis } \\
\text { Härk. and Saarim. }\end{array}$ & & LLPV620 & SGS & Food & 0.50 & 0.38 \\
\hline Amanita strobilaceovolvata Belli & & LLPV233 & SGS & Food & 0.71 & 0.71 \\
\hline Amanita aff subviscosa Belli & & LLPV218 & SGS & Food & 0.55 & 0.50 \\
\hline Amanita craseoderma Bas & & LLPV112 & SGS & Food & 0.25 & 0.27 \\
\hline Amanita crassiconus Bas & & LLPV333 & SGS & Food & 0.27 & 0.21 \\
\hline Amanita rubescens Pers. & & LLPV132 & SGS & Food & 0.52 & 0.43 \\
\hline Amanita xanthogala Bas & & LLPV159 & SGS & Food & 0.36 & 0.37 \\
\hline $\begin{array}{l}\text { Auricalaria polytricha } \\
\text { (Bull.) Quél. }\end{array}$ & Auriculariaceae & SB186 & $E F, G S, S G S$ & Food and medicinal & 0.32 & 0.25 \\
\hline Auricularia sp1 & & SB101 & $E F, G S, S G S$ & Food and medicinal & 0.57 & 0.48 \\
\hline Auricularia sp2 & & SB104 & $E F, G S, S G S$ & Food and medicinal & 0.61 & 0.61 \\
\hline Auricularia sp3 & & SB051 & $E F, G S, S G S$ & Food and medicinal & 0.51 & 0.42 \\
\hline Boletus loosii Heinem. & Boletaceae & LLPV1002 & SGS & Food & 0.34 & 0.21 \\
\hline Bulgaria sp. & Bulgariacea & SB184 & $\mathrm{EF}, \mathrm{GS}$ & Medicinal & 0.29 & 0.37 \\
\hline Cantharellus addaiensis Henn. & Cantharellaceae & LLPV100 & SGS & Food & 0.87 & 0.87 \\
\hline Cookeina sp1 & Sarcosyphaceae & SB156 & $\mathrm{EF}$ & Medicinal & $0.02-$ & 0.03 \\
\hline Cookeina sp2 & & SB193 & EF & Medicinal & 0.05 & 0.05 \\
\hline $\begin{array}{l}\text { Coprinus africanus (Pegler) Redhead, } \\
\text { Vilgalys and Moncalvo }\end{array}$ & Agaricaceae & SB 217 & $E F, G S, S G S$ & Food & 0.66 & 0.59 \\
\hline $\begin{array}{l}\text { Daldinia concentrica (Bolton) Cesati } \\
\text { and de Notaris }\end{array}$ & xylariaceae & SB189 & $\mathrm{EF}, \mathrm{GS}, \mathrm{SGS}$ & Medicinal and magic & 0.64 & 1.11 \\
\hline $\begin{array}{l}\text { Echinochaete brachypora } \\
\text { (Mont.) Ryvarden }\end{array}$ & Polyporaceae & SB073 & $E F, S G S$ & Food and medicinal & 0.28 & 0.15 \\
\hline $\begin{array}{l}\text { Ganoderma lucidum } \\
\text { (Curtis ex Fr.) P. Karst. }\end{array}$ & Ganodermataceae & SB007 & SGS & Medicinal & 0.61 & 0.42 \\
\hline Ganoderma sp. & & SB210 & $\mathrm{EF}$ & Medicinal & 0.07 & 0.02 \\
\hline Gyroporus castaneus (Bull.) Quél. & Gyroporaceae & LLPV442 & SGS & Food & 0.43 & 0.42 \\
\hline Lactarius saponaceus Verbeken & Russulaceae & LLPV079 & SGS & Food & 0.23 & 0.24 \\
\hline $\begin{array}{l}\text { Lactarius tenellus Verbeken } \\
\text { and Walleyn }\end{array}$ & & LLPV902 & SGS & Food & 0.22 & 0.34 \\
\hline Lactifluus flammans (Verbeken) Verbeken & & LLPV188 & SGS & Food & 0.72 & 0.67 \\
\hline $\begin{array}{l}\text { Lactifluus gymnocarpoides } \\
\text { (Verbeken) Verbeken }\end{array}$ & & LLPV199 & SGS & Food & 0.19 & 0.18 \\
\hline $\begin{array}{l}\text { Lactifluus heimii (Verbeken) } \\
\text { Verbeken }\end{array}$ & & LLPV164 & SGS & Food & 0.61 & 0.78 \\
\hline Lactifluus luteopus Verbeken & & LLPV191 & SGS & Food & 0.70 & 0.58 \\
\hline $\begin{array}{l}\text { Lactifluus volemoides (Karhula) } \\
\text { Verbeken }\end{array}$ & & LLPV189 & SGS & Food & 0.67 & 0.67 \\
\hline Lentinus squarrossulus Mont. & Polyporaceae & SB001 & $\mathrm{EF}, \mathrm{GS}, \mathrm{SGS}$ & Food & 0.94 & 0.28 \\
\hline Lentinus tuber-regium (Fr.) Singer & & SB093 & $E F, G S$ & Food and medicinal & 0.2 & 0.28 \\
\hline Lycoperdon sp1 & Agaricaceae & SB188 & EF & Food and medicinal & 0.11 & 0.07 \\
\hline Lycoperdon sp2 & & SB138 & $\mathrm{EF}$ & Food and medicinal & 0.12 & 0.06 \\
\hline
\end{tabular}


Table 2 Diversity and uses of useful wild mushrooms of Côte d'Ivoire (Continued)

\begin{tabular}{|c|c|c|c|c|c|c|}
\hline Species & Families & $\begin{array}{l}\text { Voucher } \\
\text { number }\end{array}$ & Distribution & $\begin{array}{l}\text { Reported } \\
\text { uses }\end{array}$ & RUV & $\mathrm{Cll}$ \\
\hline $\begin{array}{l}\text { Marrasmiellus inoderma } \\
\text { (Berk.) Singer }\end{array}$ & Marasmiaceae & SB098 & $\mathrm{EF}, \mathrm{GS}$ & Food & 0.54 & 0.20 \\
\hline Marasmiellus sp. & & SB042 & $E F, G S$ & Food & 0.21 & 0.12 \\
\hline $\begin{array}{l}\text { Octaviana ivoryana Casttelano, } \\
\text { Verbeken and Thoen }\end{array}$ & Boletaceae & LLPV214 & SGS & Positioning & 0.15 & 0.20 \\
\hline $\begin{array}{l}\text { Psathyrella tuberculata } \\
\text { (Path.) A. H. Smith }\end{array}$ & Psathyrellaceae & SB026 & $E F, G S, S G S$ & Food and medicinal & 1.20 & 1.81 \\
\hline Psathyrella sp. & & SB205 & $\mathrm{EF}, \mathrm{GS}, \mathrm{SGS}$ & Food & 0.63 & 0.58 \\
\hline Russula aff cellulata Buyck & Russulaceae & LLPV118 & SGS & Food & 0.49 & 0.48 \\
\hline Russula ciliata Buyck & & LLPV123 & SGS & Food & 0.47 & 0.49 \\
\hline Russula congoana Pat. & & LLPV048 & SGS & Food & 0.37 & 0.43 \\
\hline Russula grisea Fr. & & LLPV553 & SGS & Food & 0.51 & 0.53 \\
\hline Russula oleifera Buyck & & LLPV187 & SGS & Food & 0.51 & 0.47 \\
\hline Russula sesenagula Beeli & & LLPV127 & SGS & Food & 0.32 & 0.35 \\
\hline Russula sp. & & SB41 & GS & Food & 0.36 & 0.40 \\
\hline Schizophyllum commune Fries & Schizophyllaceae & SB061 & $E F, G S$ & Food & 0.07 & 0.07 \\
\hline $\begin{array}{l}\text { Termitomyces cf Aurantiacus } \\
\text { (R. Heim) R. Heim }\end{array}$ & Lyophyllaceae & NAK170 & SGS & Food & 0.65 & 0.73 \\
\hline $\begin{array}{l}\text { Termitomyces cf striatus } \\
\text { (Beeli) R. Heim }\end{array}$ & & SB043 & SGS & Food & 0.82 & 1.10 \\
\hline Termitomyces fuliginosus Heim & & NAK004 & SGS & Food & 0.85 & 0.87 \\
\hline $\begin{array}{l}\text { Termitomyces letestui } \\
\text { (Pat.) R. Heim }\end{array}$ & & NAK001, SB30 & GS & Food & 0.69 & 1.45 \\
\hline $\begin{array}{l}\text { Termitomyces meduis R. } \\
\text { Heim and Grassé }\end{array}$ & & NAK003, SB086 & $\mathrm{EF}, \mathrm{GS}, \mathrm{SGS}$ & Food & 0.77 & 0.98 \\
\hline $\begin{array}{l}\text { Termitomyces eurhizus } \\
\text { (Berk.) R. Heim }\end{array}$ & & NAK002 & $\mathrm{EF}$ & Food & 0.25 & 0.36 \\
\hline $\begin{array}{l}\text { Termitomyces microcarpus } \\
\text { (Berk. and Broomo) R. Heim }\end{array}$ & & NAK079 & EF & Food & 0.64 & 0.87 \\
\hline $\begin{array}{l}\text { Termitomyces schimperi } \\
\text { (Pat.) R. Heim }\end{array}$ & & NAK103 & $\mathrm{EF}$ & Food & 0.69 & 0.62 \\
\hline Termitomyces cf clypeatus & & NAK019 & $\mathrm{EF}$ & Food & 0.61 & 0.72 \\
\hline Termitomyces sp1 & & SB095 & GS & Food & 0.87 & 1.19 \\
\hline Termitomyces sp2 & & SB043 & GS & Food & 0.64 & 0.91 \\
\hline Termitomyces sp3 & & SB004 & GS & Food & 0.82 & 1.11 \\
\hline Termitomyces sp4 & & SB012 & GS & Food & 0.85 & 1.12 \\
\hline Termitomyces sp5 & & NAK037 & GS & Food & 0.70 & 1,07 \\
\hline Termitomyces sp6 & & SB10 & GS & Food & 0.86 & 1.15 \\
\hline Termitomyces sp7 & & NAK097 & GS & Food & 0.41 & 0.62 \\
\hline Volvariella earlei (Murrill) Shaffer & Volvariellaceae & SB013 & $\mathrm{EF}, \mathrm{GS}, \mathrm{SGS}$ & Food & 0.60 & 0.64 \\
\hline Volvariella volvacea (Bull.) Singer & & SB 216 & $\mathrm{EF}, \mathrm{GS}, \mathrm{SGS}$ & Food and medicinal & 0.85 & 1.43 \\
\hline Volvariella sp. & & SB041 & GS & Food & 0.06 & 0.08 \\
\hline
\end{tabular}

Abbreviations: zones phytogeographical zones of Côte d'Ivoire, EF Evergreen Forest, GS Guinean savanna, SGS Sudano-Guinean Savanna, RUV reported use value, CSI Cultural Significance Index 


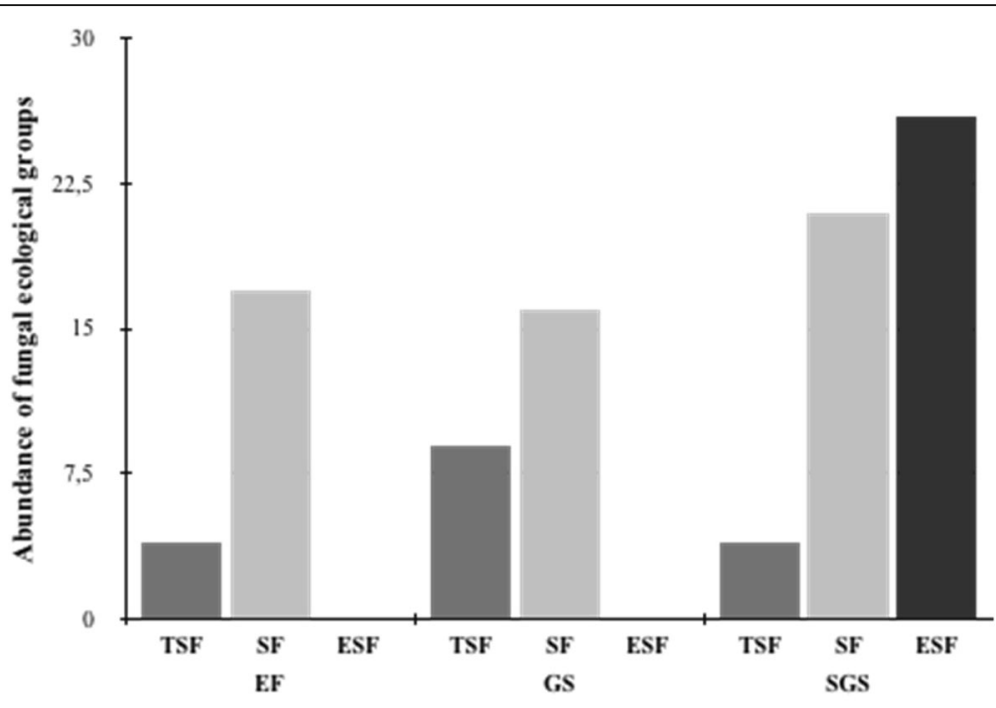

Fungal functional groups and their respective phytogeographical zones

Fig. 2 Abundance of the recorded wild useful fungi according to their respective ecological group and phytogeographical zone. Abbreviations: TSF = termitophilic symbiotic fungi, ESF = ectomycorrhizal symbiotic fungi, SF = saprophytic fungi; EF = Evergreen Forest, GS= Guinean Savanna, SGS = Sudano-Guinean savanna

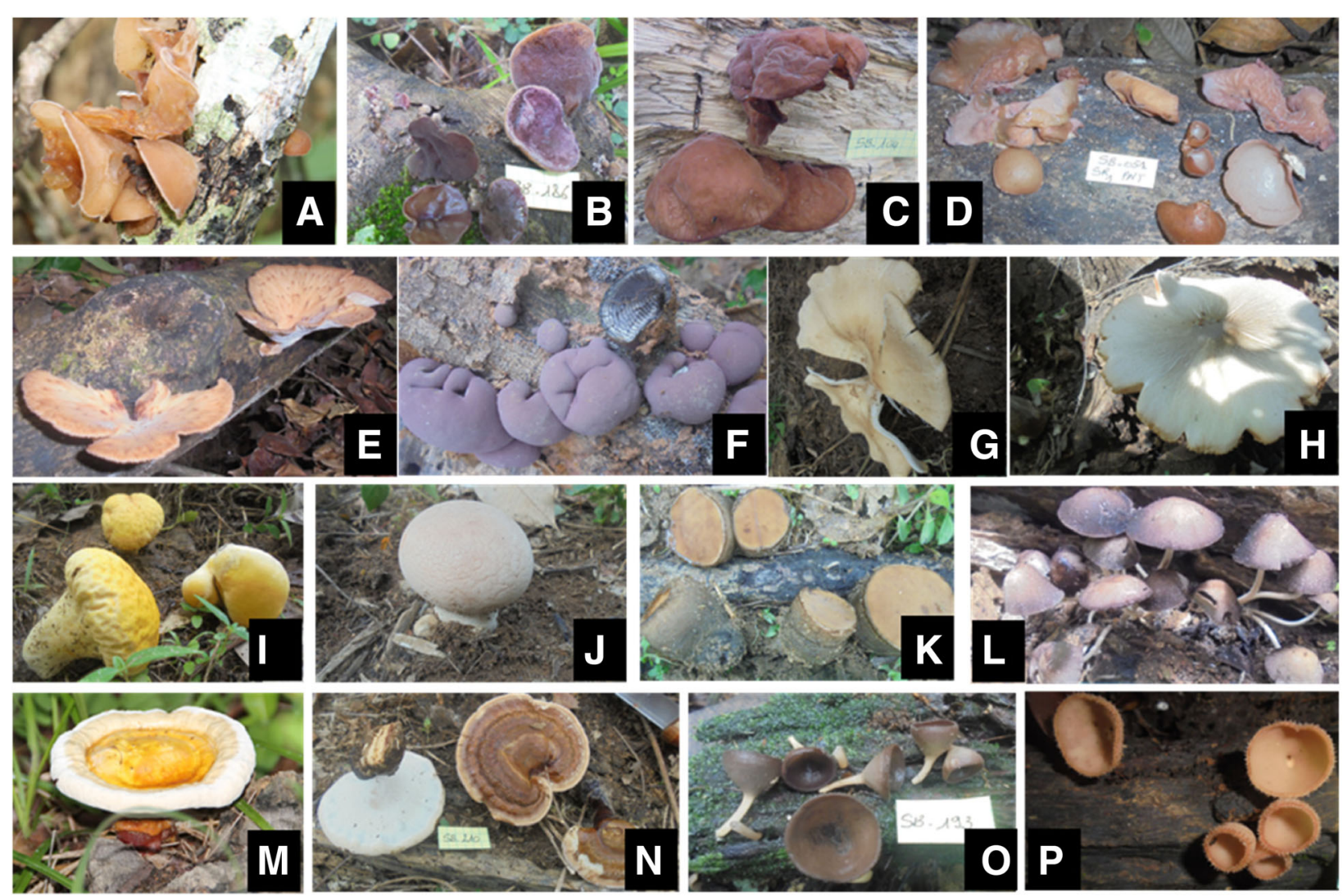

Fig. 3 Reported and recorded wild medicinal fungi of Côte d'Ivoire. a Auricularia polytricha (Mont.) Sacc. b Auricularia sp1. c Auricularia sp2. d Auricularia sp3. e Echinochaete brachypora (Mont.) Ryvarden. $\mathbf{f}$ Daldinia concentrica (Bolton) Cesati and de Notaris. $\mathbf{g}$ Lentinus tuber-regium (Fries) Fries. h Volvariella volvaceae (Bulliard) Singer. i Lycoperdon sp1. j Lycoperdon sp2. k Bulgaria sp. I Psathyrella tuberculata (Path.) A. H. Sm. m Ganoderma lucidum (Curtis ex Fr.) P. Karst. $\mathbf{n}$ Ganoderma sp. o Cookeina sp1, p Cookeina sp2 
Tables 3 Diversity and distribution of the reported wild medicinal mushrooms according to the phytogeographical and sociolinguistical groups in Côte d'Ivoire

\begin{tabular}{|c|c|c|c|c|}
\hline Fungal species & Families & Distribution & $\begin{array}{l}\text { Sociolinguistical } \\
\text { groups }\end{array}$ & Treated disease(s) \\
\hline \multirow{2}{*}{$\begin{array}{l}\text { Auricularia polytricha (Mont.) } \\
\text { Sacc. }\end{array}$} & \multirow[t]{5}{*}{ Auriculariaceae } & GS & Gouro & Peptic ulcer and hypertension \\
\hline & & $\mathrm{EF}$ & Guéré and Oubi & Menopause opportunistic diseases \\
\hline Auricalaria sp1 & & SGS & Lobi and Malinké & Peptic ulcer \\
\hline Auricularia sp2 & & SGS & Lobi and Malinké & Peptic ulcer \\
\hline Auricularia sp3 & & $\mathrm{EF}$ & Guéré and Oubi & Menopause opportunistic diseases, peptic ulcer, HIV/AIDS \\
\hline \multirow[t]{2}{*}{ Bulgaria sp. } & \multirow[t]{2}{*}{ Phacidiaceae } & EF & Baoulé & Heart condition \\
\hline & & $E F, G S$ & Baoulé & Heart condition, peptic ulcer, epilepsy \\
\hline Cookeina sp1 & \multirow[t]{2}{*}{ Sarcosyphaceae } & \multirow[t]{2}{*}{ EF } & \multirow[t]{2}{*}{ Guéré } & \multirow[t]{2}{*}{ Earache and hiccough } \\
\hline Cookeina sp2 & & & & \\
\hline \multirow[t]{2}{*}{$\begin{array}{l}\text { Daldinia concentrica (Bolton) } \\
\text { Cesati and de Notaris }\end{array}$} & \multirow[t]{2}{*}{ Hypoxylaceae } & $E F, G S, S G S$ & Baoulé, Gueré & $\begin{array}{l}\text { Hernia, stomach ache, pediatrics (stomach ache), reduction of big } \\
\text { navel of newborn babies, invigoration of kidney's activity }\end{array}$ \\
\hline & & EF & $\begin{array}{l}\text { Lobi, Oubi, } \\
\text { Koulango, Gouro, } \\
\text { Malinké, Guéré }\end{array}$ & Healing wound, boil, diarrhea, STD (gonorrhea), cheloids \\
\hline $\begin{array}{l}\text { Ganoderma lucidum } \\
\text { (Curtis ex Fr.) P. Karst. }\end{array}$ & \multirow[t]{2}{*}{ Ganodermataceae } & SGS & $\begin{array}{l}\text { Lobi, Koulango, } \\
\text { and Malinké }\end{array}$ & $\begin{array}{l}\text { Stomach ache, make giving birth easier, use as antibiotic after } \\
\text { giving birth, hemorrhoid, healing wound, rheumatism, insecticide }\end{array}$ \\
\hline Ganoderma sp. & & EF & Guéré & Pediatrics (whet new born appetite) \\
\hline $\begin{array}{l}\text { Lentinus tuber-regium } \\
\text { (Fries) Fries }\end{array}$ & Polyporaceae & GS & Baoulé & Pediatrics, burn's wound \\
\hline Lycoperdon sp1 & \multirow[t]{2}{*}{ Agaricaceae } & \multirow[t]{2}{*}{ EF } & \multirow{2}{*}{$\begin{array}{l}\text { Guéré and } \\
\text { Baoulé }\end{array}$} & \multirow{2}{*}{$\begin{array}{l}\text { Burn, pediatrics (whet new born appetite), reduction of big } \\
\text { navel of newborn babies }\end{array}$} \\
\hline Lycoperdon sp2 & & & & \\
\hline $\begin{array}{l}\text { Psathyrella tuberculata } \\
\text { (Path.) A. H. Sm. }\end{array}$ & Psathyrellaceae & $E F, G S, S G S$ & $\begin{array}{l}\text { Baoulé, Oubi, } \\
\text { Gouro, Koulango, } \\
\text { Lobi, Malinké }\end{array}$ & Peptic ulcer \\
\hline $\begin{array}{l}\text { Echinochaete brachypora } \\
\text { (Mont.) Ryvarden }\end{array}$ & Polyporaceae & EF & Baoulé & Heart condition \\
\hline $\begin{array}{l}\text { Volvariella volvaceae } \\
\text { (Bulliard) Singer }\end{array}$ & Plyteaceae & GS & Baoulé & Fat removal \\
\hline
\end{tabular}

Abbreviations: zones phytogeographical zones of Côte d'Ivoire, EF Evergreen Forest, GS Guinean Savanna, SGS Sudano-Guinean Savanna, STD sexually transmitted diseases, HIV/AIDS human immunodeficiency virus/acquired immunodeficiency syndrome

ivoryana Casttelano, Verbeken, and Thoen is used for positioning by hunters and poachers.

A total of 16 wild medicinal species belonging to 9 families (Agaricaceae, Auriculariaceae, Ganodermataceae, Hypoxylaceae, Phacidiaceae, Plyteaceae, Polyporaceae, Psathyrellaceae, Sarcosyphaceae) were inventoried during this work (Fig. 3). Auricularia polytricha (Mont.) Sacc., Auricularia sp1, Auricularia sp2, Auricularia sp3, Echinochaete brachypora (Mont.) Ryvarden, Daldinia concentrica (Bolton) Cesati and de Notaris, Lentinus tuber-regium (Fries) Fries, Volvariella volvacea (Bulliard) Singer, Lycoperdon sp1, Lycoperdon sp2, Bulgaria sp., Psathyrella tuberculata (Path.) A. H. Sm., Ganoderma lucidum (Curtis ex Fr.) P. Karst., Ganoderma sp., Cookeina sp1, and Cookeina sp2 were reported as medicinal mushrooms. These mushrooms were reported to be used for the treatment of 28 illnesses (Table 3). However, most of the reported medicinal mushrooms were found usually used for the treatment of peptic ulcer (i.e., Auricularia polytricha (Mont.) Sacc., Auricularia sp1, Auricularia sp2, Auricularia sp3, Bulgaria sp., Psathyrella tuberculata (Path.) A. H. Sm.). Finally, interviewees were rather extremely discreet with the formula and the mode of administration of these reported medicines.

\section{Vernacular nomenclature}

Each of the identified useful fungal species has a specific vernacular name within every sociolinguistical group. Indeed, only useful species were found with vernacular names. These names were given according to the ecology (palm mushroom referring to Volvariella volvacea), the presence or absence of pseudorhiza (long stipe mushroom referring to all Termitomyces species), the resemblance to an item of everyday life, the color, the taste, the capacity, and specific use by a particular ethnic group or foreign person. In the Sudano-Guinean savanna zone, the vernacular names of ectomycorrhizal species were generally given according to the host plant 
species (Additional file 1: Table S1). However, some vernacular names reported by the interviewees had no meaning. Furthermore, misidentifications of some genera having common features (i.e., Amanita and Volvariella) lead to confusions in some sociolinguistical groups. This confusion was greater in the same genus, especially with species of the genus Termitomyces, in which all the species have the same vernacular name referring to their symbiosis with termites or to the presence of a pseudorhiza (long stipe).

\section{Discussion}

Sixty-eight wild useful mushrooms were inventoried during this study. Previous studies [6] revealed 26 useful species in Côte d'Ivoire. This study gives a more complete and not exhaustive list of useful mushrooms of this country. This result might be due not only to the diversity of the visited phytogeographical zones and their respective ethnic groups but also to the long duration of data collection. Indeed, the specific diversity of wild edible mushrooms in countries is not only linked to a series of factors such as the size of the country, the diversity of ecosystems, the country's floristic composition but also the diversity of ethnic groups [6]. Furthermore, this diversity is high than those of some central and west African countries. According to [36], 42 species were inventoried in Katanga in the Democratic Republic of Congo; while in West Africa, non-exhaustive lists indicated respective diversities of 56 species in Benin, 40 species in Burkina Faso, 45 species in Senegal, and 38 species in Togo $[6,11,37-39]$. Moreover, the diversity of these mushrooms was found differing from a phytogeographical zone to another, with the greatest observed diversity in the Sudano-Guinean savanna zone. Indeed, this phytogeographical zone is dominated by ectomycorrhizal plant species and also includes forest islands and gallery forests. This diversity of ecosystems favors the occurrence of a wide variety of mushrooms especially ectomycorrhizal and Termitomyces species.

Ectomycorrhizal mushrooms with very specific fructification habitats [6] were recorded only in the SudanoGuinean savanna zone and where found known only by the populations living in the surrounding areas of the visited park (i.e., Comoé National Park). In contrast, saprotrophic and symbiotic mushrooms were found common to all the visited phytogeographical zones and represent the most used species by rural populations. Fruit bodies of these fungi occur in wooded habitats (i.e., forest for saprotrophic mushrooms and forest-savanna mosaic phytogeographical zone for Termitomyces species). This clearly shows that the identification and use of wild mushrooms depend on the phytogeographical zone but especially on the diversity of the mycophagous people found in every zone and the respective state of awareness. For example, the genus Auricularia is widely used by the Ouby and Guéré while it is rejected by the Baoule in the same phytogeographical zone in Côte d'Ivoire. Species of this genus are also highly appreciated by the Bofi Pygmies of the Central African Republic [5] and the Bariba in Northern Benin [39].

Four categories: food, medicinal, belief and myth (religious, anemometer), and recreational (ornamentation and game) of usage were reported by the rural people with a dominance of food and medicinal uses. However, the majority of inventoried species are used as food during the whole year (i.e., intense periods of farm works and the dry seasons). Sixteen wild medicinal species were reported by the interviewees. These mushrooms were considered by local populations as contributing to their physical and psychological well-being. However, this diversity seems to be underestimated. Indeed, the interviewees were found very discreet when it was question of giving information on the indigenous medicinal knowledge of fungi. This discretion was also intensified when it was questioned to give information on how these medicinal fungi where used (ingredients, preparation, and posology). The mythical and religious purposes were not frequently reported by the interviewees. This result is in contradiction with those of some authors [40], who found a spiritual interaction between wild fungi and people of Tshopo Province in the Democratic Republic of the Congo.

A set of useful mushrooms were known and identified by all the visited sociolinguistical groups. Specific vernacular names were also attributed to all the encountered useful fungal species in every sociolinguistical group. These local names were usually found descriptive and giving information on the biotope, ecology, and substrate on which the fruit body occurs, the color, side of the fruit bodies, the taste, or the effect after consumption. This vernacular nomenclature was found similar to that of the Bofi pygmies in Central African Republic [5] and the Nagot of Central Benin [41]. This nomenclature differs from the conventional Latin one on the one hand and from one African region to another on the other hand [42]. Some confusions were also observed in the identifications of a set of sociolinguistical groups with species belonging to different genera but identified as a single species (i.e., presence of volva in the species of the genera Amanita and Volvariella). Furthermore, different species of the same genus were seen with a single vernacular name (e.g., Termitomyces species). These species were systematically called "Termite cultivated's fungi" whatever the species. The most important criteria used for this vernacular nomenclature is the fructification of the species on a termite mound and the presence of a pseudorhiza in the mushrooms [7]. In short, a lack of structured and reliable vernacular nomenclature was observed during this 
work. This observation might also be due to (i) the lack of interest of current generations in mycological indigenous knowledge and (ii) the loss of fungal diversity caused by the permanent and continuous destruction of their habitats.

\section{Conclusion}

The diversity of wild useful mushrooms varies from one phytogeographical zone to another and between sociolinguistical groups in Côte d'Ivoire. The use of fungal species also varied not only from one ethnic group to another but also from one visited village to another. It also appears that these useful mushrooms are known and used by rural people mainly as food and/or medicine. Species of the genus Auricularia were reported as the most useful mushrooms of the forest zone while Termitomyces spp. and Psathyrella tuberculata are the most used species of the Guinean and the Sudano-Guinean savanna zones. This country is one the fungi-rich West African country. However, the protected areas seem to be the last important sanctuaries of these organisms.

\section{Additional file}

Additional file 1: Table S1. Vernacular nomenclature of the reported useful wild mushrooms in Côte d'lvoire. (DOCX 41 kb)

\section{Abbreviations}

CNP: Comoé National Park; CSI: Cultural Significance Index values; EUVk: Ethnomycological use value of a species for a category of use; MNP: Marahoué National Park; RUV: Reported use value; TNP: Taï National Park

\section{Acknowledgements}

The authors thank the inhabitants of the visited localities in which the ethnomycological surveys were conducted and the anonymous referees who brought important improvements to this manuscript, through their relevant remarks, suggestions and corrections.

\section{Funding}

This work was supported by funds from the International Foundation for Science (IFS Grant D_4982-2), a PhD fellowship of WASCAL Graduate Study Program Climate Change and Biodiversty and the project WABES (West African Biodiversity and Ecosystem Services) funded by the IKI initiative of the German Ministry in charge of Environment (BMU).

\section{Availability of data and materials}

The main data supporting the findings of this study have been deposited at the herbarium of WASCAL Graduate Study Program Climate Change and Biodiversity, Centre d'Excellence Africain en Changement Climatique, Biodiversité et Agriculture Durable (CEA-CCBAD). The reference codes are SB for the collection made by Soro Bakary, NAK and LPLV-L respectively for those made by N'golo Abdoulaye Koné and Linda Patricia Louyounan VaniéLeabo. The overall data are available from the authors.

\section{Authors' contributions}

BS collected the data, identified the species, analyzed and interpretation the data, and wrote the first draft of the manuscript. NAK designed the study, supplied the objectives, methods, and tools for identification. He also contributed to the interpretation of the results and to the writing of the manuscript as the responsible for corrections of the English text. LPLV-L collected part of the data and identified some of the species. SK, AB, and DK contributed to designing of the study, provided with input to the interpretation of the results and to the writing. The final version of the manuscript have been read and approved by all the authors.

\section{Ethics approval and consent to participate}

Oral consents of the rural people, their respective administrative and traditional authorities were obtained before undertaking the ethnomycological surveys.

\section{Consent for publication}

Not applicable

\section{Competing interests}

The authors declare that they have no conflict of interests.

\section{Publisher's Note}

Springer Nature remains neutral with regard to jurisdictional claims in published maps and institutional affiliations.

\section{Author details}

'Université Nangui Abrogoua, UFR des Sciences de la Nature (UFR-SN), Unité de Recherche en Ecologie et Biodiversité (UREB), 28 BP 847 28, Abidjan, Côte d'Ivoire. ${ }^{2}$ Centre de Recherche en écologie (CRE), Station de Recherche en Ecologie du Parc National de la Comoé, Bouna, Côte d'Ivoire. ${ }^{3}$ University Félix Houphouët-Boigny, WASCAL Graduate Study Program Climate Change and Biodiversity, Centre d'Excellence Africain en Changement Climatique, Biodiversité et Agriculture Durable (CEA-CCBAD), 22 BP 582 Abidjan 22, Abidjan, Côte d'Ivoire.

Received: 7 September 2018 Accepted: 10 January 2019

Published online: 18 January 2019

\section{References}

1. Malaisse F. Se nourrir en forêt claire africaine : approche écologique et nutritionnelle. Presses agronomiques de Gembloux/Centre Techn. Coop. Agricole Rurale (Wageningen). In: 384 p; 1997.

2. Härkönen $M$, niemelä T, Mwasumbi L. Tanzanian mushrooms - edible, harmful and other fungi. Norrlinia. 2003;10:1-200.

3. Buyck B. UBWOBA. Les champignons comestibles de l'Ouest du Burundi. AGCD, Rue du Trône, 4-1050, Bruxelles. Publ. Agricole, 1994 ; n³4, 123pp.

4. Eyi-Ndong HC, Degreef J, De Kesel A. Champignons comestibles des forêts denses d Afrique Centrale. In: Taxonomie et identification, vol. 10. Bruxelles: ABC Taxa; 2011. p. 255

5. Malaisse F, De Kesel A, N'gasse G. and Lognay G. Diversité des champignons consommés par les pygmées Bofi de la Lobaye en République Centrafricaine. Geo Eco-Trop 28, 2008 ; 1-11.

6. Yorou SN, Koné NA, Guissou M-L, Guelly AK, Maba DL, Ekué MRM, De Kesel A. Biodiversity and sustainable use of wild edible fungi in the Sudanian Centre of endemism: a plea for valorization. (in ectomycorrhizal symbioses in tropical and neotropical forests). CRC press. 2014;13:241-86.

7. Koné NA, Yéo K, Konaté S, Linsenmair KE. Socio-economical aspects of the exploitation of Termitomyces fruit bodies in Côte d'Ivoire: raising awareness for their sustainable exploitation. Journal of Applied Biosciences. 2013;70:5580-90.

8. Guissou KML, Sankara P, Guinko S. Phlebopus sudanicus ou la viande des Bobos, un champignon comestible dans le département de Satin au Burkina Faso. Cryptogam Mycol. 2005;26(3):195-204.

9. Adewusi SRA, Alofe FV, Odeyemi O, Afolabi OA, Oke OL. Studies on some edible wild mushroom from Nigeria: nutritional, teratogenic and toxic considerations. Plant Foods Hum Nutr. 1993;43:115-21.

10. Yorou SN, De Kesel A. Connaissances ethnomycologiques des peuples Nagot du Centre du Bénin (Afrique de l'Ouest). Proceeding of XVI the AETFAT congress, Brussels 2000. Systematic and Geographic of Plants. 2002;71:627-37.

11. Guissou KML, Lykke AM, Sankara P, Guinko S. Declining wild mushroom recognition and usage in Burkina Faso. Econ Bot. 2008;62(3):530-9.

12. Hawksworth DL. The magnitude of fungal diversity: the 1.5 million species estimate revisited. Mycol Res. 2001;105(12):1422-32.

13. O'Brien HE, Parrent JL, Jackson JA, Moncalvo JM, Vilgalys R. Fungal community analysis by largescale sequencing of environmental samples. Appl Environ Microbiol. 2005;71(9):5544-50.

14. Hawksworsth DL. Why study tropical fungi? In: Watling R, Frankland JC, Ainsworth AM, Isaac S, Robinson CH, editors. Tropical Mycology: Volume 2, Micromycetes. Wallingford: CABI Publishing; 2002. p. 204. 
15. Yorou NS. Higher mushrooms of Benin. Biodiversity Atlas of West Africa. In: Volume II Cotonou and Frankfurt/Main; 2010.

16. Parent G, Thoen D. Food value of edible mushrooms from Upper-Shaba region. Econ Bot. 1978;31:436-45.

17. Härkönen M, Saarimäki T, Mwasumbi L. Edible mushrooms of Tanzania. Karstenia. 1995;35(supplement):1-92.

18. Boa ER. Wild edible fungi : a global overview of their use and importance to people non wood forest products 17. Rome: FAO Publishing Management Services; 2004. p. 157.

19. De Kesel A, Codjia JTC, Yorou SN. Guide des champignons comestibles du Bénin. Cotonou, République du Bénin, Jardin Botanique National de Belgique et Centre International d'Ecodéveloppement Intégré (CECODI). Impr. Coco-Multimedia; 2002. p. 275.

20. Ducousso M, Bâ AM, Thoen D. Les champignons ectomycorhiziens des forêts naturelles et des plantations d'Afrique de l'Ouest : une source de champignons comestibles. Bois et forêts des tropiques. 2003;275:51-63.

21. Rammeloo J, Walleyn R. The edible fungi of Africa south of the Sahara : a literature survey. National Botanic Gar- den of Belgium, Scripta Botanica Belgica. 1993;5:62

22. Heim R. Observations sur la flore mycologique malgache, III. Trois bolets gigantesques d'Afrique et de Madagascar. Revue de Mycologie. 1936;1:3-18.

23. Locquin M. Une chanterelle comestible de la Côte d'Ivoire: Hygrophoropsis mangenotii sp. In: Nouveau Journal d'Agriculture Tropicale et de Botanique Appliquée 1; 1954. p. 359-61.

24. Yorou NS, De Kesel A. Champignons supérieurs. In: Protection de la nature en Afrique de l'Ouest: une liste rouge pour le Bénin. Ibadan, Nigeria: ITA; 2011. p. 47-60.

25. Coulibaly N. Déforestation et activités agricoles en Côte d'Ivoire : Recherche d'un nouvel équilibre. Québec: Thèse de Doctorat de I'Université de Laval; 1998. 143p

26. Yorou NS. Biodiversité, écologie et productivité des champignons supérieurs dans diverses phytocénoses de la forêt classée de Wari-Maro au Bénin (Doctoral dissertation, Thèse d'Ingénieur Agronome, FSA/UNB); 2000. p. 122.

27. Gomez-Beloz A. Plant use of the Winikina Warao : the case for questionnaire in ethnobotany. Econ Bot. 2002;56:231-41.

28. Pieroni A. Evaluation of the cultural significance of wild food botanicals traditionally consumed in northwestern Tuscany, Italy. J. Ethnobio Ethnomed. 2001;21(1):89-104.

29. Silva VA, Andrade LHC, Albuquerque UP. Revising the cultural significance index: the case of the Fulni-ô in Northeastern Brazil. Field Methods. 2006; 18(1):98-108 https://doi.org/10.1177/1.525822X05278025.

30. Garibay-Orijel R, Caballero J, Estrada-Torres A, Cifuentes J. Understanding cultural significance, the edible mushrooms case. J. Ethnobiol Ethnomed. 2007;3(4):1-18 https://doi.org/10.1186/1747-4269-3-4.

31. Heim R. Termites et champignons. In: Paris : société nouvelle des éditions boubée; 1977. p. 207.

32. Mossebo DC, Amougou A, Atangana RE. Contribution à l'étude du genre Termitomyces (Basidiomycètes) au Cameroun : écologie et systématique. Bull Soc Mycol Fr. 2002;118(3):195-249.

33. Koné NA, Soro B, Vanié- Léabo LPL, Konaté S, Bakayoko A, Koné D. Diversity, phenology and distribution of Termitomyces species in Côte d'Ivoire. Mycology. 2018.

34. Sabatier R. Le livre des champignons: Gallimard; 1987.

35. Yombiyeni P. Contribution à l'étude de la diversité taxonomique et approche écologique des polypores en forêt guinéo-congolaise au Gabon: Doctoral dissertation, UCL-Université Catholique de Louvain; 2014.

36. De Kesel A, Malaisse F. Edible Wild Food. Fungi. In: Malaisse F, editor. How to live and survive in Zambezian open forest (Miombo ecoregion). Gembloux, Belgique: Les Presses agronomiques de Gembloux; 2010. p. 41-56.

37. Bâ A, Duponnois R, Diabaté M, Dreyfus B. Les champignons ectomycorhiziens des arbres forestiers en Afrique de l'Ouest : méthodes d'étude, diversité, écologie, utilisation en foresterie et comestibilité. Editions IRD ed; 2011. p. 250.

38. Kamou H, Nadjambe P, Guelly KA, Yorou SN, Maba LD, Akpagana K. Les Champignons sauvages comestibles du Parc National Fazao-Malfakassa (PNFM) au Togo (Afrique de l'Ouest): Diversité et connaissances ethnomycologiques. Agron Afr. 2015;27(1):37-46.

39. Boni S, Yorou NS. Diversité et variabilité inter-ethniques dans la consommation de champignons sauvages de la région de N'Dali au Bénin. Tropicultura. 2015;33(4):266-76.
40. Milenge Kamalebo H, Wa Malale HNS, Ndabaga CM, Degreef J, De Kesel A Uses and importance of wild fungi: traditional knowledge from the Tshopo province in the Democratic Republic of the Congo. J Ethnobiol Ethnomed. 2018;14:13.

41. Yorou SN, De Kesel A, Sinsin B, Codjia JTC. Diversité et productivité des champignons comestibles de la forêt classée de Wari-Maro (Bénin, Afrique de l'Ouest). Syst Geogr Plants. 2001:613-25.

42. Heim R. La nomenclature mycologique des Lisongos. Cah Maboké. 1963;1:77-85.
Ready to submit your research? Choose BMC and benefit from:

- fast, convenient online submission

- thorough peer review by experienced researchers in your field

- rapid publication on acceptance

- support for research data, including large and complex data types

- gold Open Access which fosters wider collaboration and increased citations

- maximum visibility for your research: over $100 \mathrm{M}$ website views per year

At BMC, research is always in progress.

Learn more biomedcentral.com/submissions 